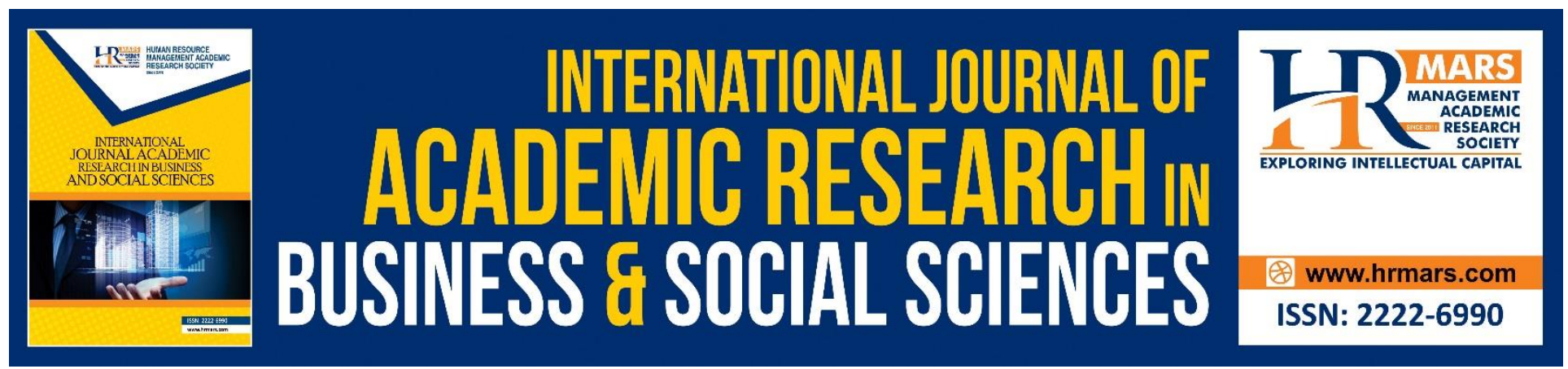

\title{
Effects of Environmental Awareness on Green Practices: A Study Among Homestay Operators in Selangor
} Yusnita Yusof, Myzatul Aini Ma'asor @ Mansor, Zainudin Awang and Hawa
Husna Ab. Ghani

To Link this Article: http://dx.doi.org/10.6007/IJARBSS/v10-i10/8022 DOI:10.6007/IJARBSS/v10-i10/8022

Received: 02 August 2020, Revised: 27 August 2020, Accepted: 17 September 2020

Published Online: 20 October 2020

In-Text Citation: (Yusof, Mansor, Awang, \& Ab. Ghani, 2020)

To Cite this Article: Yusof, Y., Mansor, M. A. M@., Awang, Z., and Ab. Ghani, H. H. (2020). Effects Of Environmental Awareness on Green Practices: A Study Among Homestay Operators in Selangor. International Journal of Academic Research in Business and Social Sciences. 10(10), 905-916.

Copyright: () 2020 The Author(s)

Published by Human Resource Management Academic Research Society (www.hrmars.com)

This article is published under the Creative Commons Attribution (CC BY 4.0) license. Anyone may reproduce, distribute, translate and create derivative works of this article (for both commercial and non-commercial purposes), subject to full attribution to the original publication and authors. The full terms of this license may be seen

at: http://creativecommons.org/licences/by/4.0/legalcode

Vol. 10, No. 10, 2020, Pg. 905 - 916

Full Terms \& Conditions of access and use can be found at http://hrmars.com/index.php/pages/detail/publication-ethics 


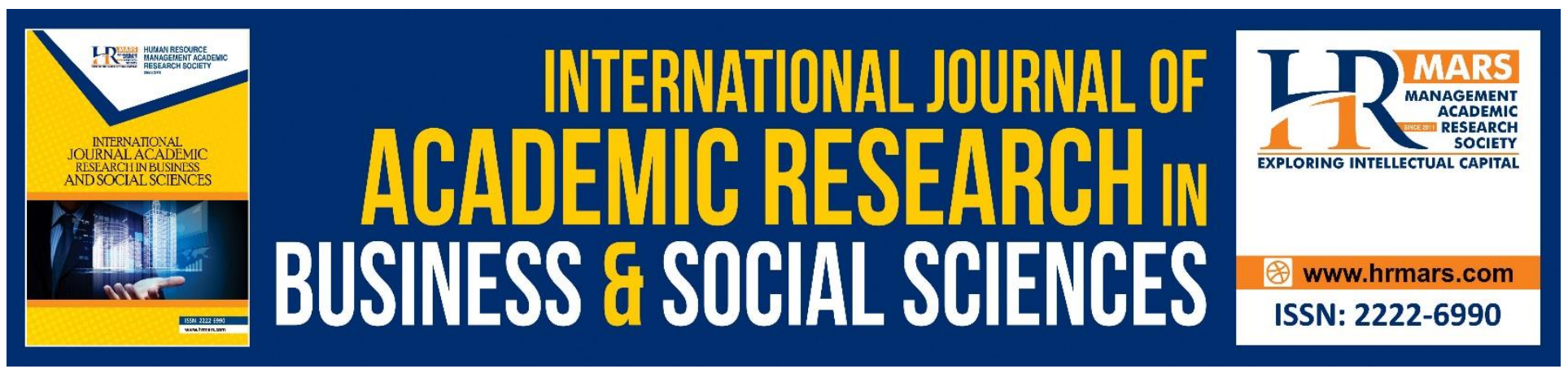

\title{
Effects of Environmental Awareness on Green Practices: A Study Among Homestay Operators in Selangor
}

\author{
${ }^{[1]}$ Yusnita Yusof, [2]Myzatul Aini Ma'asor @ Mansor, ${ }^{[3] Z a i n u d i n ~}$ \\ Awang and ${ }^{[4]}$ Hawa Husna Ab. Ghani \\ [1], [3] Faculty of Business and Management, ${ }^{[2], ~[4] ~ F a c u l t y ~ o f ~ A p p l i e d ~ S o c i a l ~ S c i e n c e s, ~ U n i v e r s i t i ~ S u l t a n ~}$ \\ Zainal Abidin, 21300 Kuala Nerus, Terengganu Malaysia \\ Email: yusnitayusof@unisza.edu.my
}

\begin{abstract}
Homestay is a human-oriented service industry. This industry partially contributes to environmental issues, especially through its day-to-day operations which involve the consumption of resources such as water and energy. Increasing tourist arrivals will also add on to the impact on the environment. In recent times, demand from consumers for eco-friendly accommodation has increased. However, some accommodation managers still operate in an outdated manner and do not fully recognise or fully appreciate the demands and environmental values associated with their business. Therefore, this study was conducted to identify the level of green practices among homestay operators based on the level of awareness about the environment. This study used quantitative methods where a questionnaire was distributed to randomly selected respondents consisting of 210 homestay operators from 16 homestays in Selangor that are registered with the Ministry of Tourism Malaysia. The analysis for this study used Statistical Package for Social Science (SPSS) software for descriptive and inferential analysis such as T test and ANOVA; as well as AMOS software to build a Structured Equation Model (SEM). Results indicate that there is no significant relation between homestay operators' awareness and green practices.
\end{abstract}

Keywords: Environmental Awareness, Green Practices, Eco-friendly, Homestay, Malaysia

\section{Introduction}

The tourism industry is an industry that will help to develop the economy but if not well planned, it will cause damage to sources of biodiversity and nature such as water, forests and marine life. Ghulam Rabbany, Afrin, Rahman, Islam and Hoque (2013); and Sadeghian (2019), stated that tourism activities have resulted in a lack of clean water in some areas, disrupted the daily lives of the surrounding population and industries, as well as caused forest destruction, damage to coral reefs at sea, habitat destruction, stress to endangered species and heightened possibility of forest fires. 
INTERNATIONAL JOURNAL OF ACADEMIC RESEARCH IN BUSINESS AND SOCIAL SCIENCES Vol. 10, No. 10, 2020, E-ISSN: 2222-6990 @ 2020 HRMARS

The adverse effects of tourism on the environment have damaged the basic tourism resources in the coastal areas and greatly affected other non-tourism economic activities. In addition, the adverse effects of tourism activities can also continue to occur because the level of visitor use is greater than the ability of the environment to regenerate. This situation will cause competition between the locals for the limited resources available. The tourism sector needs to be planned, managed and implemented in a way that the environment can be preserved, in order to bring benefit to the local population and drive social and economic development.

Being "green" is a major problem for the tourism industry especially in relation to accommodation (Jones, Hillier, \& Comfort, 2014; Eldemerdash \& Mohamed, 2013; Barber, 2012; Jin-Zhao \& Jing, 2009). According to Han (2015); Han \& Yoon (2015); Chen \& Tung (2014), in recent times, demand from consumers for eco-friendly accommodation has increased. Sucheran (2013) and Zengeni, Zengeni \& Muzambi (2013) listed the challenges for the tourism industry such as being environmentally friendly, among others. Based on an interview with a Tourism Director in Malaysia, Malaysia is considered not ready to implement green practices in accommodation due to the the general attitude, lack of knowledge, and low enforcement of rules. It is also believed that some accommodation managers still operate in an outdated manner and do not fully recognise or fully appreciate the demands and environmental values associated with their business (Butler, 2008).

Although there was a decrease of $6.7 \%$ in total of arrivals between January to December 2017 compared to January-December 2016, number is seen to increase by $8.2 \%$ compared to JanuaryDecember 2016. In terms of international tourist arrivals indicating that homestay services are still needed. The current trend in our society today is focusing on finding a "green-holiday" or a holiday that emphasises green practices. Therefore, the study on green practices among homestay operators will benefit the homestay industry in Malaysia. This study aims to identify the level of green practices among homestay operators according to demographic factors and to measure the relationship between environmental awareness and the level of green practices among homestay operators.

Apart from benefitting from the findings from this study, the operators will also be able to promote their homestay. According to Jameson \& Brownell (2012), tourism product operators who practice green practices will be classified as brand equity for such tourism products. Nowadays, the community prefers and is more interested in supporting entrepreneurs who practice green practices in their services.

\section{Literature Review}

Environmental changes and the effects that occur as a result of human daily activities are a major issue affecting the ecological system. Increasing the awareness of each individual on the importance of preserving and conserving the environment is the foundation that would lead to the love for the environment. Environmental awareness has a broad meaning; it not only implies knowledge of the environment but also the attitudes, values and skills needed to solve problems related to the environment. Moreover, awareness of the environment is an initial step that leads to more responsible behavior (Sengupta, Das, \& Maji, 2010).

This awareness of green practices has greatly influenced several sectors of the economy and with no exception, to the tourism sector as well (Andereck, 2008; Tsai, Wu \& Wang, 2014). Entrepreneurs in this economic sector have begun to focus on green practices that can minimise resource consumption, reduce waste and subsequently eliminate environmental pollution. Moreover, the hospitality and accommodation sector is one of the sectors in the tourism industry that contributes 
INTERNATIONAL JOURNAL OF ACADEMIC RESEARCH IN BUSINESS AND SOCIAL SCIENCES Vol. 10, No. 10, 2020, E-ISSN: 2222-6990 @ 2020 HRMARS

significantly to environmental issues, especially during production and through day-to-day operations, involving the consumption of resources such as water and energy (Chikita, 2012; Nezakati, View, \& Nezakati, 2015; Zengeni, Zengeni, \& Muzambi, 2013).

Homestay is a community-based industry that offers tourists a natural experience in the local rural lifestyle (Jabil Mapjabil, Siti Asma Mohd Rosdi, Munir Shuib, \& Sharmini Abdullah, 2011). Visitors who participate in homestay programmes will experience for themselves the peacefulness of the countryside as well as enjoy the deliciousness and diversity of traditional food in Malaysia.

Previous studies have shown that there are three core components of green practices - energy management, waste management, and water conservation (Chan, Wong, \& Lo, 2009; Mensah, 2006; Styles, Schönberger, \& Martos, 2013; Zhao, 2011). Due to energy consumption in homestays and other accommodation requiring high costs, energy management is the most important practice to control electricity consumption in hotels without compromising customer satisfaction (ICF International, 2008; Kannan \& Kannan, 2016; Mendes \& Santos, 2014). In the accommodation sector, water is used for bathing, hygiene requirements, cleaning, laundry, cooking, drinking and gardening, among others (Alonso-Almeida, 2012; Bohdanowicz, 2006). However, according to Bohdanowicz (2006), accommodation operators only monitor water expenditure as a whole without paying attention to each part of consumption due to lack of adequate monitoring and reporting. Moreover, this waste management weakness tends to produce greenhouse gases (GHG) (Rüd \& Marth, 2012). Therefore, water conservation is also an effective practice to preserve the environment. Garbage heaps from the tourism industry, especially from the accommodation sector, are considered one of the negative effects on the environment (Radwan, Jones, \& Minoli, 2012; Zorpas, Lasaridi, Voukkali, \& Loizia, 2012). According to Wang (2012) and Mensah (2006), waste management is recognised as a green practice that promotes the protection of environmental quality, image formation, organisational reputation, and cost efficiency in the accommodation sector.

Doody (2009) also identified several barriers to implementing green practices in the hotel and accommodation industry, such as lack of knowledge among hotel operators or homestay operators on environmental issues and strategies, managerial attitudes, employee support, financial problems, customer attitudes, operations and law. Environmental knowledge is a term used to imply knowledge of environmental problems and possible solutions to them (Zsoka, Szerenyi, Szechy, \& Kocsis, 2013) In addition, the study conducted by Sabri \& Teoh (2006) was to determine the relationship between environmental awareness and practices in conserving the environment. The study was conducted on 80 employees of Schmidt BioMedTech Sdn Bhd. The findings of the study proved that more than $70 \%$ of respondents have a high level of concern for the environment. However, the level of green consumption practice was still shown to be moderate. Environmental studies conducted in higher education institutions show that the awareness and level of practice among students in Malaysia is at a good level (Zurina \& Norjan, 2003). However, students' willingness to practice environmental practices is still low. The findings of this study are in line with the study of Abu Samah (2008) who stated that students have a good awareness of environmental problems but this awareness is not translated into actual practice.

Based on a study conducted by Safari, Salehzadeh, Panalhi \& Abolghasemian (2018), it was shown that environmental knowledge and awareness influence the green behaviour of individuals. This means that as environmental knowledge and awareness increases within an organisation, green behaviour also increases. Their study also found that individual attitudes, environmental commitment and green practice commitment also influence an individual's green behaviour. 
INTERNATIONAL JOURNAL OF ACADEMIC RESEARCH IN BUSINESS AND SOCIAL SCIENCES Vol. 10, No. 10, 2020, E-ISSN: 2222-6990 @ 2020 HRMARS

\section{Methodology}

The aim of the study is to examine effects of environmental awareness on green practices among homestay operators in Selangor, Malaysia. The approach used in this study is based on nonexperimental studies, i.e. survey research using a questionnaire. There were 147 operators chosen using simple random sampling out of 454 operators from 16 homestays registered with the Ministry of Tourism, Arts and Culture Malaysia. Until December 2017, Selangor has served the highest total number of rooms within peninsular Malaysia with 724 rooms.

Using a structured questionnaire, questions were divided into four parts, namelyPart $A$ (demographic), Part B (awareness), Part C (knowledge) and Part D (green practices). Questions in Part $B, C$ and $D$ were measured using the Likert Scale, represented from scale 1 (Strongly Disagree) until scale 10 (Strongly Agree).

A pilot study was carried out among 30 respondents from homestays in Selangor. The Cronbach's Alpha value for awareness was 0.965 . Meanwhile, for knowledge and green practices, the values were shown to be high at 0.962 and 0.967 . This means that the set of items in the questionnaire is consistent enough to measure the needed variables and has a good reliability value, thus is suitable for further study. This study used SPSS software to analyse descriptive statistics and inferential statistics such as T-test and ANOVA test; meanwhile, AMOS software is used to conduct factor analysis and test the relationship between environmental awareness and environmental knowledge of green practices. Prior to analysing the data, the researcher performed factor analysis and normality tests. Normality tests are performed to determine whether the study data have a normal or abnormal distribution. This procedure is important to ensure the normal distribution of data and allows researchers to perform parametric analysis, such as hypothesis testing and inferential statistics (Chua, 2014).

\section{Findings}

The results of this study are discussed based on the study objectives, namely: 1) identify the level of green practices among homestay operators according to demographic factors; and 2) measure the relationship between environmental awareness and the level of green practices of homestay operators. Descriptive analysis for this study was carried out using SPSS version 21.0 software. 
INTERNATIONAL JOURNAL OF ACADEMIC RESEARCH IN BUSINESS AND SOCIAL SCIENCES Vol. 10, No. 10, 2020, E-ISSN: 2222-6990 @ 2020 HRMARS

Table 1.1: Summary of Homestay Operator Profile

\begin{tabular}{|c|c|c|}
\hline Characteristics & $\begin{array}{r}\text { Frequency } \\
\text { (n:147) }\end{array}$ & $\begin{array}{r}\text { Percentage } \\
\%\end{array}$ \\
\hline \multicolumn{3}{|l|}{ Gender } \\
\hline Male & 76 & 51.7 \\
\hline Female & 71 & 48.3 \\
\hline \multicolumn{3}{|l|}{ Age } \\
\hline 21 - 30 years old & 5 & 3.4 \\
\hline 31 - 40 years old & 5 & 3.4 \\
\hline 41 - 50 years old & 23 & 15.6 \\
\hline $51-60$ years old & 57 & 38.8 \\
\hline 61 - 70 years old & 53 & 36.1 \\
\hline 70 and above & 4 & 2.7 \\
\hline \multicolumn{3}{|l|}{ Race } \\
\hline Malay & 146 & 99.3 \\
\hline Others & 1 & 0.7 \\
\hline \multicolumn{3}{|l|}{ Marital Status } \\
\hline Single & 9 & 6.1 \\
\hline Married & 119 & 81.0 \\
\hline Widow/Widower & 19 & 12.9 \\
\hline \multicolumn{3}{|l|}{ Education } \\
\hline Primary School & 30 & 20.4 \\
\hline SRP/PMR & 19 & 12.9 \\
\hline SPM & 87 & 59.2 \\
\hline STPM & 2 & 1.4 \\
\hline Diploma & 7 & 4.8 \\
\hline Degree & 1 & 0.7 \\
\hline Others & 1 & 0.7 \\
\hline
\end{tabular}

Based on Table 1.1, of a total of 147 respondents to the questionnaire distributed, 76 of them were male entrepreneurs (51.7\%) while the remaining 71 were female entrepreneurs (48.3\%). In terms of age, the majority of homestay operators were aged 51 years and above (114 respondents or $77.6 \%$ ). Meanwhile, 33 respondents or $22.4 \%$ of homestay operators were aged 50 years and below.

Almost all homestay operators are Malays, namely a total of 146 respondents or $99.3 \%$ percent of all respondents. One respondent is Chinese $(0.7 \%)$. In addition, the majority of homestay operators are married, i.e 119 respondents or $81 \%$ of the total number of operators.. Nine respondents, namely $6.1 \%$ of respondents are still single and 19 respondents or $12.9 \%$ have the status of widower or widow.

The highest level of education of homestay operators is a Bachelor's Degree, owned by one person or $0.7 \%$ of the total respondents. 87 entrepreneurs or $59.2 \%$ completed their education at the Sijil Pelajaran Malaysia (SPM) level, while 2 respondents or $1.4 \%$ completed up to Sijil Tinggi Pengajian Malaysia (STPM). In addition, 49 entrepreneurs or 33.3\% completed school at the primary school level and SRP/PMR level. 
INTERNATIONAL JOURNAL OF ACADEMIC RESEARCH IN BUSINESS AND SOCIAL SCIENCES Vol. 10, No. 10, 2020, E-ISSN: 2222-6990 @ 2020 HRMARS

\section{Inferential Analysis}

$\mathrm{H} 1$ : There is a significant difference in the level of green practices of homestay operators according to demographic factors.

1.0 Influence of green practices according to demographic factors

Inference analysis in this study used two tests, namely t-test and ANOVA. Both tests were used to identify the differences that exist between the green practices of entrepreneurs based on the demographic factors of the respondents. In this study, t-test was used to analyse the gender of the respondents while ANOVA test was used to analyse demographic factors such as marital status, age and educational status.

\subsubsection{Differences in green practices according to gender}

The t-test was used because gender has only two means, namely male and female. Table 1.2 shows not statistically significant difference $(t=1.016$, sig $=0.404)$ between males and females. Since the $p$ value is greater than the significance level $(0.05)$, these findings indicate that there is not statistically significant difference in green practices between male or female entrepreneurs.

Table 1.2: Differences in green practices and gender

\begin{tabular}{llllllll}
\hline Variables & & N & Min & SP & t & df & $\begin{array}{l}\text { Sig(2- } \\
\text { tailed) }\end{array}$ \\
\hline Green Practices & Men & 76 & 8.6398 & .74217 & 1.016 & 145 & 0.404 \\
& Women & 71 & 8.5141 & .75757 & & & \\
\hline
\end{tabular}

\section{Differences in green practices according to marital status}

One-way ANOVA test was conducted to test the difference in the level of green practices according to the marital status of the respondents. The ANOVA test was chosen to test this hypothesis because marital status, age and level of education have more than two means. Based on Table 1.3, the F value $=1.952$ and the value of Sig $=0.146$. Since the $p$-value is greater than the significance level $(0.05)$, these findings indicate that there is not statistically difference between green practices and marital status. This means that there is no difference in the level of green practices between single, married and widowed respondents.

Table 1.3: Differences in green practices according to marital status

\begin{tabular}{lllllll}
\hline Factor & Source & Total Square & DK & $\begin{array}{l}\text { Min } \\
\text { Square }\end{array}$ & F & Sig. \\
\hline Marital & Between & 2.166 & 2 & 1.083 & 1.952 & .146 \\
Status & Group & & & & & \\
& In Group & 79.899 & 144 & .555 & & \\
& Total & 82.065 & 146 & & & \\
\hline
\end{tabular}

\section{Differences in green practices according to age factor}

One-way ANOVA test was conducted to test the difference in the level of green practices according to the age of the respondents. Table 1.4 shows that the value of $F=2.024$ and the value of Sig $=0.079$. Since the $p$-value is greater than the significance level $(0.05)$, these findings indicate that there is not 
INTERNATIONAL JOURNAL OF ACADEMIC RESEARCH IN BUSINESS AND SOCIAL SCIENCES Vol. 10, No. 10, 2020, E-ISSN: 2222-6990 @ 2020 HRMARS

statistically difference between green practices and age. This means that there is no difference in the level of green practices between respondents of different ages.

Table 1.4: Differences in green practices according to age

\begin{tabular}{llllcll}
\hline Factor & Source & Total Square & DK & $\begin{array}{l}\text { Min } \\
\text { Square }\end{array}$ & F & Sig. \\
\hline Age & Between & 5.497 & 5 & 1.099 & 2.024 & .079 \\
& Group & & & & & \\
& In Group & 76.568 & 141 & .543 & & \\
& Total & 82.065 & 146 & & & \\
\hline
\end{tabular}

\section{Differences in green practices according to educational background}

Subsequent ANOVA analysis involved the educational status of the respondents. Table 1.5 showsthat the $\mathrm{F}$ value $=0.934$ and the value of Sig $=0.461$. The pvalues in excess of 0.05 indicate that there is not statistically significant difference between green practices and educational standards. This means that there is no difference in the level of green practices between respondents who have an educational background of up to primary school, SRP/PMR, SPM, STPM, diploma or a Bachelor's Degree.

Table 1.5: Differences in green practices according to educational background

\begin{tabular}{cllllll}
\hline Factor & Source & Total Square & DK & $\begin{array}{l}\text { Min } \\
\text { Square }\end{array}$ & F & Sig. \\
\hline Education & Between & 2.630 & 5 & .526 & .934 & .461 \\
& Group & & & & & \\
& In Group & 79.435 & 141 & .563 & & \\
& Total & 82.065 & 146 & & & \\
\hline
\end{tabular}

$\mathrm{H}$ 2: Environmental awareness has a significant relationship with the level of green practices of homestay operators.

Based on Table 1.6, the relationship between environmental awareness and green practices is insignificant. The direct effect value is measured through the beta coefficient value. Thus, Hypothesis $\mathrm{H} 2$ is rejected because environmental awareness has no significant relationship with green practices.

Table 1.6: Regression Value

\begin{tabular}{|c|c|c|c|c|c|c|c|}
\hline & & & Estimate & S.E. & C.R. & $\mathbf{P}$ & Result \\
\hline $\begin{array}{l}\text { Green } \\
\text { Practices }\end{array}$ & $<--$ & Awareness & .099 & .040 & 2.492 & .013 & $\begin{array}{l}\text { Not } \\
\text { Significant }\end{array}$ \\
\hline
\end{tabular}

\section{Discussion}

Through the t-test carried out, green practices is not affected by every factor, namely gender (Carlsen, Getz \& Ali-Knight, 2010), marital status, age and level of education (Kollmuss \& Agyeman, 2002). However, the findings of this study contradict the findings of Braun (2010) which inidate that business entrepreneurs among women have a higher tendency to implement green practices compared to men. Another study (Laroche, Bergeron \& Barbaro-Forleo, 2001; Han, Hsu, Lee \& Sheu, 2011; Tsai, 
INTERNATIONAL JOURNAL OF ACADEMIC RESEARCH IN BUSINESS AND SOCIAL SCIENCES Vol. 10, No. 10, 2020, E-ISSN: 2222-6990 @ 2020 HRMARS

Wu \& Wang, 2014) found that female respondents were more willing to spend their money on green products. Dipietro, Cao \& Partlow (2013) in their study also stated that female respondents are more likely to buy environmentally friendly products, prefer to receive information about green products or services as well as prioritise businesses that apply green practices.

Meanwhile, the findings of the study for marital status, are in contrast to the study of Tsai, Wu \& Wang (2014) which showed that respondents who are single have a higher tendency to apply green practices compared to married respondents. Agag (2019) stated that younger users showed greater willingness to pay more for hotels that practise towel reuse programmes than older users. In addition, hotel guests under the age of 30 showed a higher desire to book green hotels and were more willing to pay more for green hotels than users aged between 29 and 60 years. In addition, Sukhu \& Scharff (2018) found that respondents who have a higher level of education were more likely to carry out green practices. Their higher knowledge has influenced their views regarding finding environmentally friendly products or implementing green practices in daily life.

Based on the analysis conducted, environmental awareness has no significant relationship with the green practices of homestay operators. Environmental awareness alone does not help to determine a person's behaviour. They may have awareness but this is not the determinant of their actions. In this study, researchers found that an individual's environmental behaviour cannot occur simultaneously because their consciousness is influenced by several other factors, such asost-savings, convenience and environmental factors. For example, illegal disposal and open burning of garbage is easier than proper disposal of garbage (i.e., segregating and packing garbage to be disposed of at a landfill), which ultimately leads to air pollution and poor waste management. Although individuals are aware of the effects of their actions, they tend to ignore these due to convenience factors.

\section{Conclusion}

Based on the analysis conducted, environmental awareness has no significant relationship with the green practices of homestay operators. Environmental awareness alone does not help to determine a person's behaviour. They may have awareness but this is not the determinant of their actions. In this study, researchers found that an individual's environmental behaviour cannot occur simultaneously because their consciousness is influenced by several other factors, such as costsavings, convenience, and environmental factors. For example, illegal disposal and open burning of garbage are easier than proper disposal of garbage (i.e., segregating and packing garbage to be disposed of at a landfill), which ultimately leads to air pollution and poor waste management. Although individuals are aware of the effects of their actions, they tend to ignore these due to convenience factors.

To encourage this green effort, incentives, subsidies, or various environmental programs can be offered to motivate homestay operators to implement green practices in homestay operations. An incentive given to entrepreneurs is a good form of assistance to them as the homestay industry consists of small and medium scale services. In line with this, the Malaysian government needs to introduce a certificate of recognition to the entrepreneur to implement green practices in their homestay services. Such recognition can upgrade homestay status or as branding to the homestay. Apart from homestay training courses that are often implemented by the government regularly to entrepreneurs, modules containing environmental awareness programs and environmental issues should also be provided to operators. Moreover, ongoing environmental awareness programs can 
INTERNATIONAL JOURNAL OF ACADEMIC RESEARCH IN BUSINESS AND SOCIAL SCIENCES Vol. 10, No. 10, 2020, E-ISSN: 2222-6990 @ 2020 HRMARS

help entrepreneurs increase their knowledge to preserve the environment in their area, know their duties, and how their every action will affect the environment.

\section{Limitations and Future Recommendations}

This study used a small sample size and was only conducted in homestays located in the state of Selangor. The findings of this study do not reflect the situation and green practices in the context of homestay operators in Malaysia as a whole. In order to get a more comprehensive and in-depth view, future studies need to be implemented among homestay visitors as well as superiors involved in the homestay industry. The findings of the studies from various parties will help homestay management to build strategies and improve their services in line with green practices. In addition, future studies can also identify barriers to and the motivation of homestay operators to implement green practices in their homestay services.

Green practices are often associated with high costs and burdensome entrepreneurs but previous studies have emphasised that some operating costs can be reduced. Green practices also add value to to the reputation of the homestay service, showing businesses carrying out their corporate social responsibility and improving environmental conditions. Thus, this study can be used to provide understanding to entrepreneurs and players in the homestay industry to improve their green practices. This study has proven that high environmental knowledge and environmental awareness will influence the green practices of entrepreneurs.

\section{Acknowledgement}

This study was funded by Universiti Sultan Zainal Abidin under Grant No: UniSZA/2018/DPU/05 Code Project R0034-R005.

\section{References}

Agag, G. (2019). Understanding the determinants of guests' behaviour to use green P2P accommodation. International Journal of Contemporary Hospitality Management.

Al-Shourah, A. A. (2007). The relationship between environmental management practices (EMP) and hotel performance: EMP Drivers and The Moderating Role of Perceived Benefits. Unpublished doctoral dissertation, Universiti Sains Malaysia.

Andereck, K. L. (2008). Tourist perception of environmentally friendly innovations. BEST Educational Network Think Tank VII, Innovations for Sustainable Tourism.

Abu Samah, A. (2008). Kita Hanya Menumpang. Pemanasan Global. Estidotmy, 76, 16-17.

Bohdanowicz, P. (2006). Responsible resource management in hotels: Attitudes, indicators, tools and strategies. Royal Institute of Technology. Retrieved from http://kth.divaportal.org/smash/record.jsf?pid=diva2:10873

Braun, P. (2010). Going green: women entrepreneurs and the environment. International Journal of Gender and Entrepreneurship.Bohdanowicz (2006)

Butler, J. (2008). The compelling "Hard Case" for "Green" hotel development. Cornell Hospitality Quarterly, 49(3), 234-244. http://doi.org/10.1177/ 1938965508322174

Carlsen, J., Getz, D., \& Ali-Knight, J. (2001). The environmental attitudes and practices of family businesses in the rural tourism and hospitality sectors. Journal of sustainable tourism, 9(4), 281-297.

Chan, W., Wong, K., \& Lo, J. (2009). Hong Kong hotels' sewage: Environmental cost and saving 
INTERNATIONAL JOURNAL OF ACADEMIC RESEARCH IN BUSINESS AND SOCIAL SCIENCES

Vol. 10, No. 10, 2020, E-ISSN: 2222-6990 @ 2020 HRMARS

technique. Journal of Hospitality \& Tourism Research, 33(2), 329-346

Chen, M. F., \& Tung, P. J. (2014). Developing an extended theory of planned behavior model to predict consumers' intention to visit green hotels. International Journal of Hospitality Management, 36, 221-230. http://doi.org/10.1016/j.ijhm.2013.09.006

Chikita, M. (2012). Analyzing the impact on consumer satisfaction, behavior and attitudes by using eco-friendly practices and products in Surfers Paradise/Gold Coast city hotels, Australia. Haaga-Helia Univeristy of Applied Sciences

Chua, Y. P. (2014). Asas Statistik penyelidikan. McGraw-Hill Education (Malaysia) Sdn. Bhd

DiPietro, R. B., Cao, Y., \& Partlow, C. (2013). Green practices in upscale foodservice operations. International Journal of Contemporary Hospitality Management.

Doody, H. (2009). What are the barriers to implementing environmental practices in the Irish hospitality industry?: A literature review. Shannon College of Hotel Management.

Eldemerdash, J. M., \& Mohamed, L. M. (2013). Exploring obstacles of employing environmental practices: The case of Egyptian green hotels. Journal of Human Resources in Hospitality \& Tourism, 12(3), 243-258.

GhulamRabbany, M., Afrin, S., Rahman, A., Islam, F., \& Hoque, F. (2013). Environmental effects of tourism. American Journal of Environment, Energy and Power Research, 1(7), 117-130

Han, H., Hsu, L. T. J., Lee, J. S., and Sheu, C. (2011), "Are lodging customers ready to go green? An examination of attitudes, demographics, and eco-friendly intentions", International Journal of Hospitality Management, Vol. 30 No. 2, pp. 345-355

Han, H. (2015). Travelers' pro-environmental behavior in a green lodging context: Converging ValueBelief-Norm Theory and the Theory of Planned Behavior. Tourism Management, 47, 164-177.

Han, H., \& Yoon, H. J. (2015). Hotel customers' environmentally responsible behavioral intention: Impact of key constructs on decision in green consumerism. International Journal of Hospitality Management, 45, 22-33Han, 2015;

ICF International. (2008). Energy management in your hotel. New Delhi. Retrieved from https://smallb.sidbi.in/sites/default/files/knowledge_base/guidebook_hotel.pdf

Jameson, D. A., \& Brownell, J. (2012). Telling your hotel's "green" story: developing an effective communication strategy to convey environmental values. Cornell Hospitality Tools, 3(2), 6-17.

Jones, P., Hillier, D., \& Comfort, D. (2014). Sustainability in the global hotel industry.International Journal of Contemporary Hospitality Management, 26(1), 5-17.

Kannan, S., \& Kannan, S. (2016). The energy management strategies for the hotel industry in Papua New Guinea. Asian Journal of Business Management, 04(03), 111-116.

Kollmuss, A., \& Agyeman, J. (2002) Mind the Gap: Why do people act environmentally and what are the barriers to pro-environmental behavior?, Environmental Education Research, 8:3, 239-26

Laroche, M., Bergeron, J., \& Barbaro-Forleo, G. (2001). Targeting consumers who are willing to pay more for environmentally friendly products. Journal of Consumer Marketing, 18(6), 503-520.

Mendes, J. P., \& Santos, S. (2014). Energy management in four and five star hotels in Algarve (Portugal). Turizam International Scientific Journal, 18(3), 95-112.

Mensah, I. (2006). Environmental management practices among hotels in the Greater Accra Region. Journal Hospitality Management, 25(3), 414-431.

Nezakati, H., View, T., \& Nezakati, H. (2015). Green Tourism Practices in Malaysia Hospitality And Tourism Selected Issues in.

Radwan, H. R. I., Jones, E., \& Minoli, D. (2012). Solid waste management in small hotels: A comparison 
INTERNATIONAL JOURNAL OF ACADEMIC RESEARCH IN BUSINESS AND SOCIAL SCIENCES

Vol. 10, No. 10, 2020, E-ISSN: 2222-6990 @ 2020 HRMARS

of green and non-green small hotels in Wales. Journal of Sustainable Tourism, 20(4), 533-550.

Rüd, S., \& Marth, R. (2012). Achieving sustainable wastewater and organic solid waste management taking advantage of the clean development mechanism. In W. L. Filho (Ed.), Climate change and the sustainable use of water resources (pp. 101-125). Berlin: Springer-Verlag.

Sabri, M. F., \& Teoh, Y. Y. (2006). Tahap Keperihatinan Alam Sekitar dan Amalan Penggunaan Hijau Pengguna di Petaling Jaya, Selangor. Pertanika Journal of Social Science \& Humanity, 14(2), 95-109.

Sadeghian, M. M. (2019). Negative Environmental Impacts of Tourism, a Brief Review.

Safari, A., Salehzadeh, R., Panahi, R., \& Abolghasemian, S. (2018). Multiple pathways linking environmental knowledge and awareness to employees' green behavior. Corporate Governance: The international journal of business in society.

Sengupta, M., Das, J., \& Maji, P. K. (2010). Environmental awareness and environment related behaviour of twelfth grade students in Kolkata: Effects of stream and gender. Anwesa, 5(January), 1-8.

Siti-Nabiha, A. K., George, R. A., Abdul Wahid, N., Amran, A., Abustan, I., \& Mahadi, R. (2011). A field survey of environmental initiatives at selected resorts in Malaysia. World Applied Sciences Journal, 12(Special Issue of Tourism \& Hospitality), 56-63.

Sucheran, R. (2013). Environmental management in the hotel and lodge sector in KwaZulu-Natal, South Africa. University of KwaZulu-Natal. Retrieved from http://researchspace.ukzn.ac.za/bitstream/handle/10413/9419/Sucheran_Reshma_2013.pd f?sequence $=1 \&$ isAllowed $=y$

Sukhu, A., \& Scharff, R. (2018). Will 'doing right'lead to 'doing well'? An examination of green behavior. Journal of consumer marketing.

Tsai, Y. H., Wu, C. T., \& Wang, T. M. (2014). Attitude towards green hotel by hoteliers and travel agency managers in Taiwan. Asia Pacific Journal of Tourism Research, 19(9), 1091-1109.

Wang, R. (2012). Investigations of important and effective effects of green practices in restaurants. Procedia -Social and Behavioral Sciences, 40, 94-98.

Zengeni, N., Zengeni, D. M. F., \& Muzambi, S. (2013). Hoteliers' perceptions of the impacts of green tourism on hotel operating costs in Zimbabwe: The case of selected Harare hotels. Australian Journal of Business and Management Research, 2(11), 64-73.

Zhao, C. (2011). An analysis of hotels' green activities and its influence on hotels' projected image using a mixed methodology. Purdue University.

Zorpas, A. A., Lasaridi, K., Voukkali, I., \& Loizia, P. (2012). Solid waste from the hospitality industry in Cyprus. WIT Transactions on Ecology and The Environment, 166, 41-49.

Zsoka, A., Szerenyi, Z. M., Szechy, A., \& Kocsis, T. (2013). Greening due to environmental education? Environmental knowledge, attitudes, consumer behavior and everyday pro-environmental activities of Hungarian high school and university students. Journal of Cleaner Production, 48, 126-138. Retrieved from http://www.elsevier.com/authorsright

MahadiM, Z., \& Yusof, N. (2003). Kesedaran Alam Sekitar: Tinjauan Awal di kalangan Pelajar Universiti Kebangsaan Malaysia. Prosiding Seminar Kebangsaan Pengurusan Persekitaran. Bangi: Universiti Kebangsaan Malaysia. 